\title{
Slab Application of Fiber Reinforced Lightweigt Concrete
}

\author{
Bengi Arisoy
}

\begin{abstract}
In this paper slab application of propylene reinforced lightweight concrete is discussed. The effect of fibers on flexural strength of lightweight concrete was investigated and possible slab use of propylene fiber reinforced lightweight concrete was discussed. In the frame work of the study, fiber reinforced lightweight concrete was produced with using short propylene fibers, lightweight aggregate (perlite), cement, sand, plasticizer and water. Propylene fibers are used provide ductility in place of steel reinforcement. Perlite used as aggregate provides lightweight. Cement and sand component are used for strength. The cube, cylinder and beam samples were prepared to determine material and mechanical properties of fiber reinforced lightweight concrete. Possible use of fiber reinforced lightweight concrete as slab; the slabs (panels) with the dimension of $13 \times 50 \times 150 \mathrm{~cm}$ were produced. The panels were tested in four-point bending test to determine flexural strength (MOR, modulus of rupture). Total of seven slab samples were prepared. One of the samples is produced for control sample. The control sample did not contain any fibers or perlite. Three of the samples were produced using both fiber and perlite.
\end{abstract}

Keywords-ductility, fiber reinforced concrete, lightweight concrete, slabs

\section{Introduction}

Lightweight concrete is typically used by the building construction industry as non-structural wall panels, masonry blocks and architectural exterior finishing. Mechanical properties of lightweight concrete are considerably lower than normal weight concrete, thus structural use (as load bearing structural member) of lightweight concrete is construction materials. It is proven that fortification of plain cementitious materials by random short fibers increased the limited. In order to use lightweight concrete for structural purpose, the material must be engineered to show adequate strength, ductility or a combination of both. By advancement in fiber reinforced concrete, lightweight concrete reinforced with randomly distributed short fibers becomes desirable tensile and flexural strength of cementitious composites [1][2][3][4][5].

Ductility is extremely important property in order to use the concrete in structural purposes. Especially flooring slab applications of the concrete require large flexural strength.

Bengi Arisoy

Department of Civil Engineering/ Ege University

Turkey

\section{Propylen Fiber Reinforced Lightweight Aggregates Slabs}

In this paper, slabs studied are intended to be flexural load bearing slabs, reinforced with short random fibers with a \% 1.5 fiber fraction. Propylene fibers used have 0.91 $\mathrm{g} / \mathrm{cm} 3$ of density, $12 \mathrm{~mm}$ of length and $3500 \mathrm{MPa}$ of elasticity modulus (Figure 1). Perlite used has $0.08 \mathrm{~g} / \mathrm{cm} 3$ of density and 10-120 micron of diameter (Figure 2).

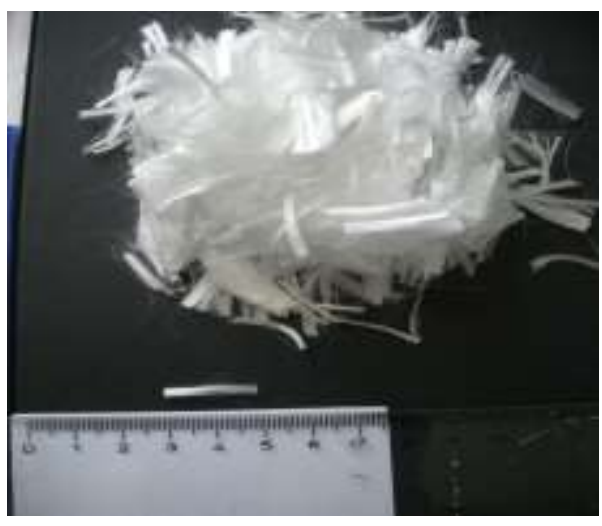

Figure 1. Propylen fibers

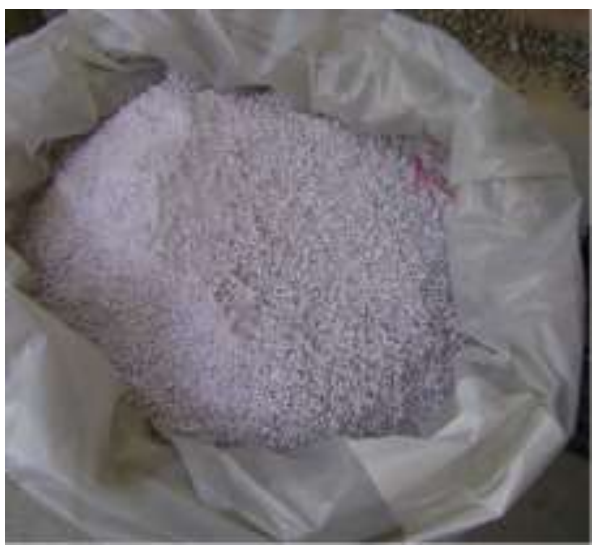

Figure 2. Lightweight aggregate

The samples

were produced cement/water/sand/lightweight aggregate/fiber ratio of the concrete produced is $1 / 0.4 / 2 / 0.05 / 0.015$, respectively. The control sample is produced with same cement/water/sand ratio without fibers and lightweight aggregate (perlite). Mix compositions of the samples are given in Table I. 
Proc. Of the International Conference on Advances in Civil, Structural and Construction Engineering - CSCE 2016 Copyright (C) Institute of Research Engineers and Doctors. All rights reserved.

ISBN: 978-1-63248-101-6 doi: 10.15224/ 978-1-63248-101-6-06

TABLE I. MIX COMPOSITIONS RATIOS TOCEMENT

\begin{tabular}{|l|c|c|c|c|c|}
\hline \multicolumn{1}{|c|}{ Sample } & Cement & Water & Sand & Perlite & Fiber \\
\hline Control Mix & 1 & 0.4 & 2 & - & - \\
\hline Mix_1 & 1 & 0.4 & 2 & - & 0.015 \\
\hline Mix_2 & 1 & 0.4 & 2 & 0.05 & 0.015 \\
\hline
\end{tabular}

Mechanical and material properties are measured by using standard $15 \mathrm{~cm}$ in diameter $/ 30 \mathrm{~cm}$ in height cylinder samples and $10 \mathrm{~cm}$ wide $/ 10 \mathrm{~cm}$ deep $/ 60 \mathrm{~cm}$ length beam samples. Three samples were used for each testing. Summary of mean material and mechanical properties is given in Table II.

TABLE II. MATERIAL AND MECHANICAL PROPERTIES OF SAMPLES

\begin{tabular}{|l|c|c|c|}
\hline \multicolumn{1}{|c|}{ Sample } & $\begin{array}{c}\text { Density } \\
(\mathbf{g} / \mathbf{c m 3})\end{array}$ & $\begin{array}{c}\text { Elasticity } \\
\text { Modulus (MPa) }\end{array}$ & $\begin{array}{c}\text { Compressive } \\
\text { Strength (MPa) }\end{array}$ \\
\hline Control Mix & 2.26 & 40576 & 66.87 \\
\hline Mix_1 & 2.17 & 40673 & 67.36 \\
\hline Mix_2 & 2.14 & 38826 & 58.35 \\
\hline & $\begin{array}{c}\text { Flexural } \\
\text { Strength } \\
\text { (MPa) }\end{array}$ & $\begin{array}{c}\text { Splitting Tensile } \\
\text { Strength } \\
\text { (MPa) }\end{array}$ & $\begin{array}{c}\text { Elasticity } \\
\text { Modulus (MPa) }\end{array}$ \\
\hline Control Mix & 6.33 & 2.89 & 40576 \\
\hline Mix_1 & 7.06 & 2.99 & 40673 \\
\hline Mix_2 & 7.03 & 2.37 & 38826 \\
\hline
\end{tabular}

\section{Experimental Program}

A total of seven slabs were produced. The slabs were $13 \mathrm{~cm}$ thick, $50 \mathrm{~cm}$ wide and $1500 \mathrm{~cm}$ length. One of the slabs was produced using Control Mix concrete, and it is named Control Slab, three of the slabs were produced using Mix_1 concrete and named Slab_1, three of the slabs were produced using Mix_2 concrete and named Slab_2. The samples were tested by four-point testing to measure flexural strength (Figure 3).

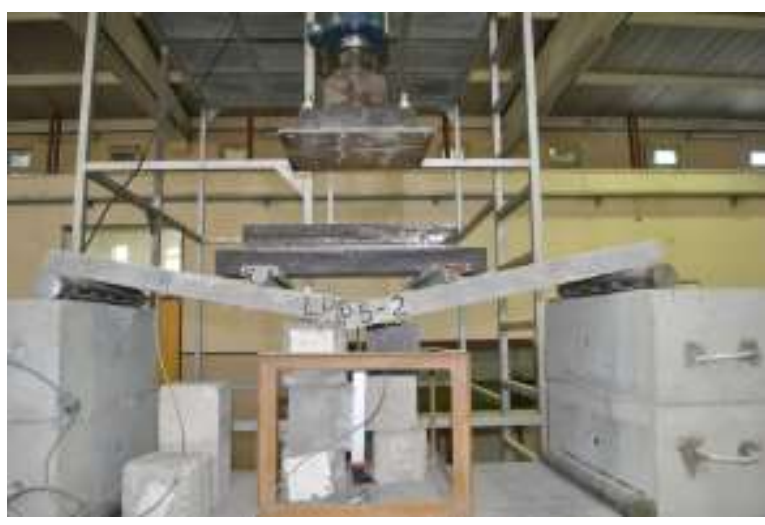

Figure 3. Flexural testing

The load-displacement graphics is given in Figure 4. Displacement is measured at the mid-point of the panels. All samples exhibited brittle failure. The samples contain fiber did not exhibit ductile behavior.

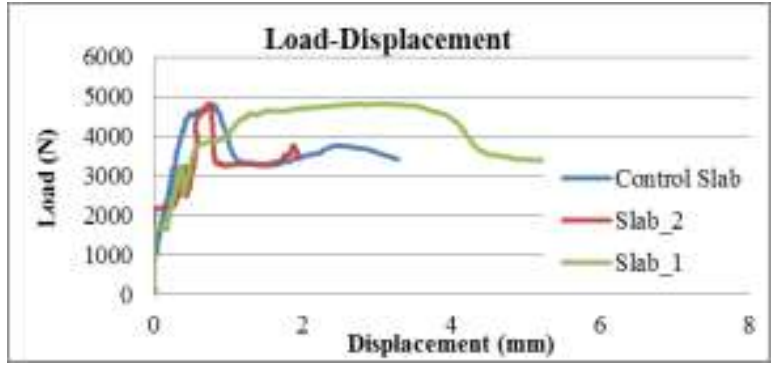

Figure 4.Load-Displacement Curve

The flexural strength of the slab samples is given in Table 3

TABLE III. FLEXTURA STRENGTH OF SLABS

\begin{tabular}{|c|c|}
\hline Sample & Flexural Strength (MPa) \\
\hline Control Slab & 85.8 \\
\hline Slab_1 & 89.7 \\
\hline Slab_2 & 85.2 \\
\hline
\end{tabular}

\section{Conclusion}

In the present paper, an experimental research on flexural behavior of slabs cast with different component; with perlite and propylene fibers, is presented. On the basis of the obtained results

- the use of propylene fiber in concrete appears a little effect on ductility. This result indicates that either the amount of the fiber is low or the properties of fiber are not suitable to the concrete strength,

- the adoption of lightweight aggregates allows reducing the self-weight of the composite material with respect to the traditional concrete. In order to provide further decrease in composite, the amount of perlite could be increased,

- the failure mode in all slabs was brittle.

\section{References}

[1] Aveston, J., Cooper, G.A., and Kelly, A. (1971). Single and multiple fracture. The properties of fiber composites, Science and Technology Press Ltd.,England, 15-24.

[2] Reinhardt, H.W. and Naaman, A.E. (1992). High Performance Fiber Reinforced ement Composites. Chapman \& Hall Press.

[3] Li, V.C. and Leung, C.K.Y. (1992). Steady-State and Multiple Cracking on ShortRandom Fiber Composites. J. of Engineering Mechanics, V.118, No.11,pp.2246-2264

[4] Li, V.C. and Wu, H.C. (1992). Conditions for Pseudo StrainHardening in Fiber Reinforced Brittle Matrix Composites. J. of Applied Mechanics Reviews.

[5] Wu, H.C. and Li, V. (1995). Stochastic Process of Multiple Cracking in Discontinuous Random Fiber reinforced Brittle Matrix Composites. International Journal of Damage Mechanics, V.4,pp.83-102. 
Proc. Of the International Conference on Advances in Civil, Structural and Construction Engineering - CSCE 2016 Copyright (C) Institute of Research Engineers and Doctors. All rights reserved.

ISBN: 978-1-63248-101-6 doi: 10.15224/ 978-1-63248-101-6-06

About Author (s):

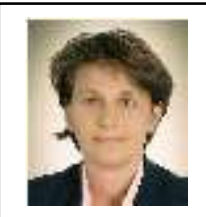

Bengi Arisoy received her Bachelor of Engineering Degree from Department of Civil Engineering, Dokuz Eylul University, Izmir Turkey in 1987, Masters and $\mathrm{PhD}$ Degrees in Civil Engineering from Faculty of Engineering, Wayne State University, Detroit, MI, USA in 1997 and 2004, respectively.

Currently she is working as Associate Professor in Department of Civil Engineering, Ege University, Izmir, Turkey.

Her research interests are Structural Dynamics, Strengthening Reinforced Concrete Buildings, and Masonry Structures.

Currently she is studying two projects founded nationally:

"Performance of Reinforced Concrete Beam-Column Connection Strengthened with Carbon Fiber Reinforced Plastic Sheets",

"Strengthening of Reinforced Concrete Beam-Column Connection" 